\title{
PENGARUH KONSENTRASI GETAH POHON KAYU JAWA (Lannea coromandelica) TERHADAP KONDUKTIVITAS MEMBRAN BLEND KITOSAN-POLIVINIL ALKOHOL- LITIUM SEBAGAI MEMBRAN ELEKTROLIT
}

\author{
Effect of Concentration of Latex Kayu Jawa (Lannea coromandelica) on Conductivity of Blend \\ Chitosan-Polyvinyl Alcohol-Lithium Membrane as Electrolyte Membrane
}

\author{
*Masriana, Mery Napitupulu, dan Siang Tandi Gonggo \\ Pendidikan Kimia/FKIP - Universitas Tadulako, Palu - Indonesia 94118 \\ Received 06 June 2017, Revised 04 July 2017, Accepted 07 August 2017
}

\begin{abstract}
This research aims to study the concentration effect percentage weight of kayu jawa latex on the conductivity of membranes made from chitosan-PVA-lithium. The ionic conductivity of the membrane chitosan-PVA-lithium-latex kayu jawa was measured by impedance spectroscopy. The measurement results showed that membrane with the addition of $15 \%$ latex kayu jawa provided the highest conductivity values of $10.99353 \times 10^{-4} \mathrm{~S} / \mathrm{cm}$. Characterization of the polymer electrolyte batteries that made from chitosan-PVA-lithium with the addition of latex kayu jawa have voltage of 1.5 Volts compared to commercial batteries that have tension was 1.5 Volts. These results indicated that latex kayu can be used as a filler to increase the ionic conductivity.
\end{abstract}

Keywords: Chitosan, polyvinyl alcohol, lithium (Li), latex, kayu jawa.

\section{Pendahuluan}

Energi merupakan salah satu hal yang sangat dibutuhkan manusia. Seiring dengan perkembangan ilmu pengetahuan dan teknologi saat ini semakin meningkat pula energi yang dibutuhkan akan tetapi cadangan sumber energi fosil kian hari kian menipis. Bahkan isu yang beredar bahwa bahan bakar fosil tersebut diperkirakan akan habis beberapa tahun ke depan. Oleh karena itu, perlu adanya alat penyimpan energi, salah satunya adalah baterai ion litium. Penelitian tentang pengembangan beragam alat penyimpan energi semakin marak dibicarakan dan para peneliti berlomba-lomba untuk mencari bahan yang dapat dijadikan sebagai membran yang bisa meningkatkan konduktivitas energi pada baterai. Salah satu hal yang penting adalah baterai ion litium tersebut bersifat ramah lingkungan (biodegradable) (Rahmawati \& Gonggo, 2013).

Baterai merupakan sel elektrokimia yang menghasilkan tegangan konstan sebagai reaksi kimia (Minami, dkk., 2005). Baterai dikategorikan dalam 2 jenis yaitu baterai primer dan sekunder. Baterai primer merupakan baterai yang pemakaiannya hanya sekali dan reaksi kimia yang terlibat dalam bahan elektroda bersifat irreversible. Contohnya yaitu baterai karbon seng seperti baterai $\mathrm{ABC}$ dan alkaline. Sedangkan baterai sekunder merupakan baterai yang pemakaiannya lebih dari satu kali atau berulang-ulang dan reaksi kimia yang terlibat bersifat reversible contohnya baterai ion litium (Robinson, 1997).

Pengembangan terbaru dari teknologi baterai ion litium adalah penggunaan polimer elektrolit sebagai separator antara bagian anoda dan katodanya.

*Correspondence

Masriana

Program Studi Pendidikan Kimia, Fakultas Keguruan dan IImu

Pendidikan, Universitas Tadulako

e-mail: masrianaalthafunnisa@gmail.com

Published by Universitas Tadulako 2017
Berhubungan dengan maraknya isu lingkungan mengenai produk yang ramah lingkungan maka pengembangan polimer elektrolit yang dapat terbiodegradasi menjadi suatu topik penelitian yang menarik dan layak untuk dikembangkan (Rahmawati \& Gonggo, 2013).

Membran kitosan yang dibuat akan dimodifikasi dengan penambahan bahan pembentuk struktur semi interpenetrating polimer network (semi-IPN) yaitu poli vinil alkohol (PVA) karena sifat mekaniknya yang baik (Hassan \& Pepas, 2000). Penambahan PVA pada kitosan dimaksudkan agar meningkatkan kekuatan pada membran kitosan. PVA merupakan salah satu polimer sintetik dengan keunggulan seperti hidrofisilitas dan kompatibilitas, tidak beracun, kandungan air yang tinggi, sifat mekanik yang kuat stabilitas kimia yang baik dibanding polimer sintetik lainnya dan ini merupakan biodegradable (Erizal, dkk., 2013). Tapi polimer elektrolit yang mengandung garam litium cenderung mengkristal pada suhu kamar. Oleh karena itu, salah satu usaha yang dapat dilakukan adalah dengan menambahkan zat aditif yang dapat mengurangi potensi tersebut. Salah satunya yaitu dengan menggunakan filler. Filler yang dikembangkan saat ini utuk mengurangi material yang bersifat beracun dan berbahaya (nonbiodegradable) adalah filler yang berasal dari alam (biodegradable) seperti getah pohon kayu jawa (Lannea coromandelica).

Pohon kayu jawa berasal dari negara India, karena itu, biasa juga disebut pohon india, yang merupakan pohon yang tumbuh tinggi hingga $14 \mathrm{~m}$ (Dinesh, 2008). Pohon ini memiliki banyak kegunaan, diantaranya sebagai antiseptik yang dihasilkan dari ekstrak daunnya (Imam \& Moniruzzaman, 2014). Getah pohon kayu jawa mengandung alumina dan silika (Saehana, 2014). Adanya silika dan alumina ini yang merupakan oksida asam dan cenderung dapat mengikat ion positif $\left(\mathrm{H}^{+}, \mathrm{Li}^{+}\right)$sehingga melalui oksida 
silika dan alumina diharapkan dapat meningkatkan mobilitas ion $\mathrm{Li}^{+}$dalam matriks membran, sehingga konduktivitas membran meningkat. Oleh karena itu, perlu dilakukan penelitian tentang pengaruh getah pohon kayu jawa pada membran kitosan-PVA-Li dalam meningkatkan konduktivitasnya.

Tulisan ini dimaksudkan untuk mempelajari pengaruh konsentrasi persen berat getah pohon kayu jawa terhadap konduktivitas membran berbahan dasar kitosan-PVA-litium.

\section{Metode}

\section{Alat dan Bahan}

Alat yang digunakan dalam pembuatan membran yaitu: gelas kimia, gelas ukur, pipet tetes, labu ukur, botol semprot, erlenmeyer, neraca analitik, cawan petri, spatula, pinset, aluminium foil, hot magnetic stirrer, magnetic stirrer, dan oven. Sedangkan alat yang digunakan analisis morfologi yaitu: mikrometer skrup, multimeter tipe 410, Fourier Transform Infra Red (FTIR), spektroskopi impedansi merk Egilent 4980A dan seperangkat Scanning Electron Microscope (SEM) yang dirangkai dengan Energy Dispersive X-ray Spectrometer (EDS). Bahan yang digunkan yaitu padatan kitosan, padatan Poli vinil alkohol (Merck), padatan $\mathrm{LiClO}_{4}$ (Sigma Aldrich) getah pohon kayu jawa, asam asetat glasial (Merck) dan aquades.

\section{Prosedur Penelitian}

Pembuatan membran elektrolit kitosan- polivinil alkohol- litium dengan penambahan getah pohon kayu jawa

Pembuatan membran elektrolit kitosan- PVAlitium dengan penambahan getah pohon kayu jawa, mula-mula kitosan dilarutkan sebanyak $30 \%$ berat dari berat kitosan + PVA dengan menggunakan asam asetat $1 \%$ sebanyak $50 \mathrm{~mL}$, lalu diaduk dengan menggunakan magnetic stirer. Setelah itu PVA dilarutkan sebanyak $70 \%$ berat dari berat kitosan + PVA dengan menggunakan aquades sebanyak $50 \mathrm{~mL}$ dan di panaskan dengan menggunakan hot magnetic stirer secara pelan-pelan hingga suhu $80{ }^{\circ} \mathrm{C}$ lalu. Setelah keduanya larut, larutan tersebut disaring kemudian dicampur dan diaduk kembali hingga kedua campuran homogen. Setelah homogen ditambahkan litium sebanyak $2 \%$ berat dari berat total material membran ke dalam campuran tersebut dan dilarutkan kembali hingga semuanya homogen. Setelah itu ditambahkan getah pohon kayu jawa sebanyak $5 \%$ berat dari berat total material membran ke dalam campuran dan dihomogenkan kembali. Setelah homogen, campuran dituang pada cawan petri lalu dioven selama 2 jam pada suhu $75{ }^{\circ} \mathrm{C}$, kemudian dikeringkan dalam pada suhu kamar selama 2 minggu. Penambahan getah divariasikan komposisinya yaitu: $0 \%, 5 \%, 10 \%, 15 \%$, dan $20 \%$.

\section{Karakterisasi membran elektrolit}

Karakterisasi yang dilakukan terhadap membran adalah analisis gugus fungsi dan uji konduktivitas dan membandingkan nilai voltase baterai berbahan dasar elektrolit polimer dengan baterai komersial. Analisis gugus fungsi ditentukan menggunakan FTIR (Fourier Transform Infrared). FTIR adalah suatu spektrofotometer yang digunakan untuk menganalisis gugus fungsi yang terdapat pada suatu material. Prinsip kerja dari spektrofotometer ini adalah interaksi antara cahaya dan materi pada panjang gelombang 800-10.000 nm (Joni, 2007).

Sinar inframerah apabila dilewatkan melalui cuplikan senyawa-senyawa organik, maka sejumlah frekuensi diserap sedangkan frekuensi yang lain diteruskan/ditransmisikan tanpa diserap (Sastrohamidjojo, 2007). FTIR Prestige 21 Shimadzu merupakan alat yang digunakan dalam karakterisasi membran pada penelitian ini, dimana sampel membran dibuat pelet dengan melakukan pressure yang setara dengan 10 ton. Selanjutnya dirunning menggunakan FTIR (Marareza, 2014)

Konduktivitas membran ditentukan menggunakan spektroskopi impedansi merek Egilent 4980A. Hasil pembacaan spektroskopi impedansi digambarkan dalam impedansi atau hambatan suatu arus listrik dari sampel yang diukur. Pengukuran konduktivitas dilakukan pada kondisi kering. Nilai konduktivitas membran dapat dihitung berdasarkan konfigurasi elektroda (Syahril, 2012).

\section{Uji perbandingan voltase antara membran elektrolit dengan beterai komersial}

Pengujian voltase membran elektolit kitosan-PVALitium-getah, dilakukan pembuatan baterai mengacu pada penelitian Subban, dkk (1996), pada polimer elektrolit, dimana teknik pembuatan baterai yang dilakukan adalah dengan memotong bahan polimer elektrolit kitosan-PVA-litium-getah menjadi ukuran 5 $\times 4 \mathrm{~cm}$, yang selanjutnya diletakkan diantara katoda dan anoda. Elektroda yang digunakan dalam pembuatan baterai ini yakni zink dan karbon (grafit), dimana zink bertindak sebagai katoda dan karbon (grafit) bertindak sebagai anoda.

Baterai yang dibuat dari elektrolit polimer diukur dengan menggunakan multimeter digital tipe 410 . Baterai komersial yang digunakan dalam pengukuran ini menggunakan baterai merk $\mathrm{ABC}$ besar sebanyak 2 buah. Pengukuran baterai elektrolit polimer dilakukan dengan mengukur voltase baterai elektrolit polimer pada komposisi penambahan getah 5\%-20\% $(\mathrm{w} / \mathrm{w})$ dan tanpa penambahan getah ( $0 \%$ getah), lalu dibandingkan dengan voltase pada baterai komersial tersebut (Mohamed, dkk., 1995).

\section{Hasil dan Pembahasan}

\section{Analisis FTIR}

Hasil analisis gugus fungsi FTIR Kit-PVA-Ligetah pohon kayu jawa menghasilkan spektrum seperti pada Gambar 1. 
1

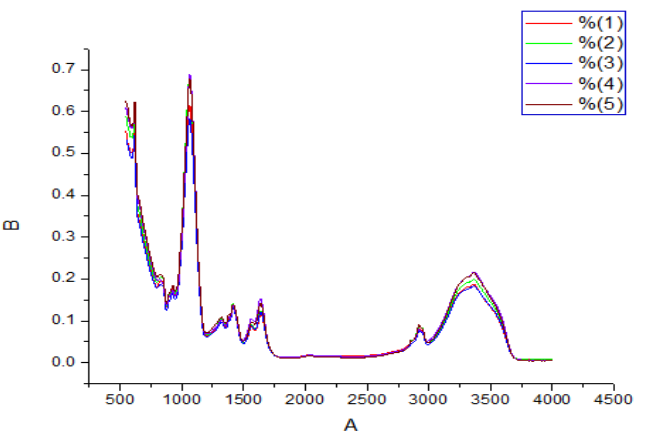

Gambar 1. Spektrum FTIR membran kit-PVA-LiGetah $0 \%, 5 \%, 10 \%, 15 \%$ dan $20 \%(\mathrm{w} / \mathrm{w})$.

FTIR (Fourier Transform Infrared) merupakan suatu instrumen yang digunakan untuk mengukur resapan radiasi inframerah pada daerah bilangan gelombang $4000-400 \mathrm{~cm}^{-1}$ (Fessenden $\&$ Fessenden, 1986). Pengukuran dengan alat spektroskopi FTIR bertujuan untuk mengetahui berbagai tipe ikatan pada bilangan gelombang tertentu (Sastrohamidjojo, 2007).

Berdasarkan hasil analisis menggunakan FTIR membran elektrolit yang disintesis adalah membran padat yang merupakan campuran dari kitosanpolivinil alkohol-litium-getah kayu jawa dengan menggunakan variasi $0 \%, 5 \%, 10 \%, 15 \%$, dan $20 \%$ (w/w). Hasil Spektrum FTIR sampel menunjukkan beberapa pita-pita serapan inframerah yang beragam. Pada semua membran, pita lebar pada daerah panjang gelombang 3000-3500 $\mathrm{cm}^{-1}$ yang menunjukkan adanya gugus $-\mathrm{OH}$ dan gugus $-\mathrm{NH}_{2}$ yang saling tumpang tindih (Sastrohamidjojo, 2007). Serapan melebar pada daerah tersebut menunjukkan adanya ikatan hidrogen intermolekul dan intramolekul yang terbentuk dalam molekul-molekul yang mengandung gugus hidroksi ataupun gugus $-\mathrm{NH}_{2}$ tersebut, dimana dalam hal ini gugus - $\mathrm{OH}$ berasal dari senyawa polivinil alkohol dan gugus $-\mathrm{NH}_{2}$ berasal dari senyawa kitosan (Paradossi, dkk., 1996).

Adanya gugus - $\mathrm{OH}$ dalam spektrum ini seperti halnya alkohol alifatik diperkuat dengan munculnya pita tajam antara $1200-1000 \mathrm{~cm}^{-1}$ yang merupakan karakteristik untuk gugus -Si-O. Hal ini dapat dilihat pada sampel tanpa penambahan getah dan dengan penambahan getah $5-20 \%(\mathrm{w} / \mathrm{w})$ dengan munculnya satu pita tajam pada sampel tanpa penambahan getah dan membentuk dua pita serapan pada $5-20 \%(\mathrm{w} / \mathrm{w})$ getah. Pita pada daerah panjang gelombang antara 1400 dan $1350 \mathrm{~cm}^{-1}$ yang menunjukkan adanya gugus metil (Sastrohamidjojo, 2007).

Pita serapan yang muncul pada daerah 1650-1600 $\mathrm{cm}^{-1}$ adalah pita serapan khas kitosan yang merupakan vibrasi tekuk dari $-\mathrm{NH}$ yang menunjukkan keberadaan gugus $-\mathrm{NH}_{2}$. Hal tersebut menunjukkan juga terjadinya interaksi antara polivinil alkohol dan kitosan (Marareza, 2014).

Ion litium yang berinteraksi dengan gugus $-\mathrm{OH}$ yang berasal dari polivinil alkohol dan gugus amida dari kitosan akan menyebabkan terjadi pengkelatan logam litium itu sendiri (Razak, dkk., 2008). Spektrum FTIR pada daerah sidik jari yaitu senyawa yang terdapat dalam getah yaitu silika yang umumnya diketahui memiliki puncak yang khas dan kuat antara bilangan gelombang $1600-1500 \mathrm{~cm}^{-1}$ yang menunjukkan adanya gugus fungsi $-\mathrm{Si}-\mathrm{O}-\mathrm{Si}$, adanya gugus fungsi $-\mathrm{Si}-\mathrm{O}-\mathrm{Si}$ diperkuat dengan adanya puncak pada bilangan gelombang sekitar $800 \mathrm{~cm}^{-1}$ yang menunjukkan adanya -Si-O (Mohamed, dkk., 1995). Selain itu, pita serapan yang tampak pada daerah sidik jari disebabkan adanya getaran dari $\mathrm{SiO}_{2}$.

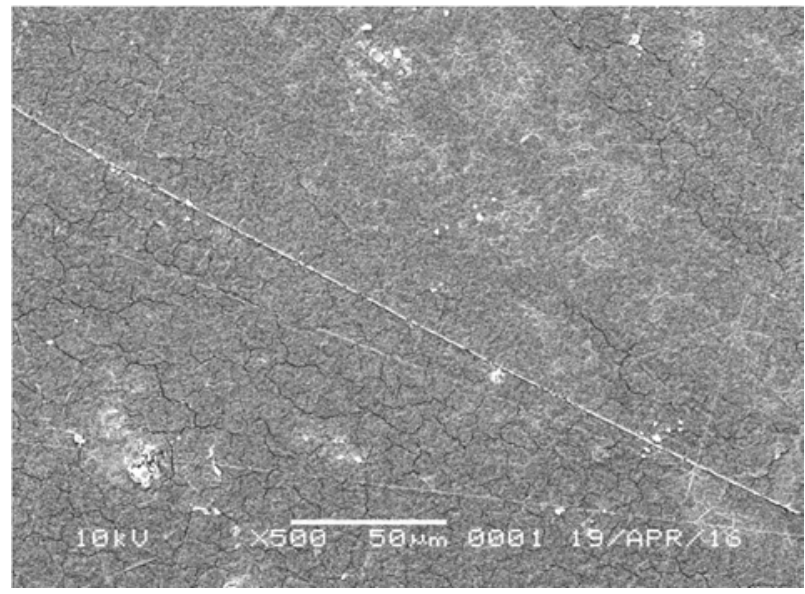

Gambar 2 (a). Analisis SEM membran Kit-PVA-Ligetah $5 \%(\mathrm{w} / \mathrm{w})$

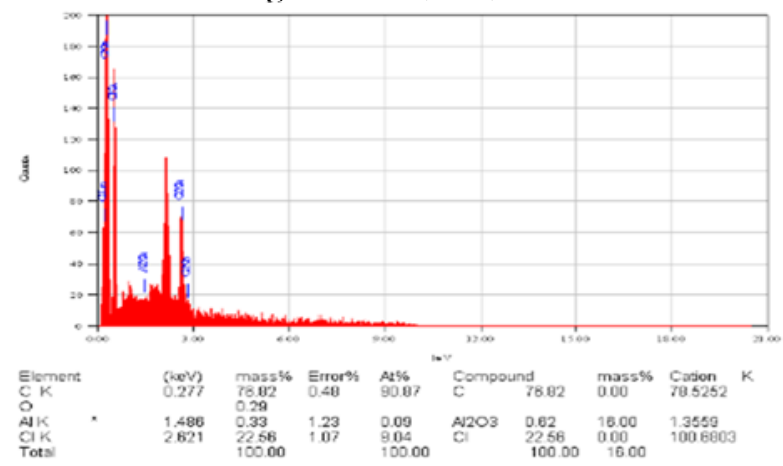

Gambar 2 (b). Analisis EDAX membran Kit-PVA-Ligetah $5 \%(\mathrm{w} / \mathrm{w})$

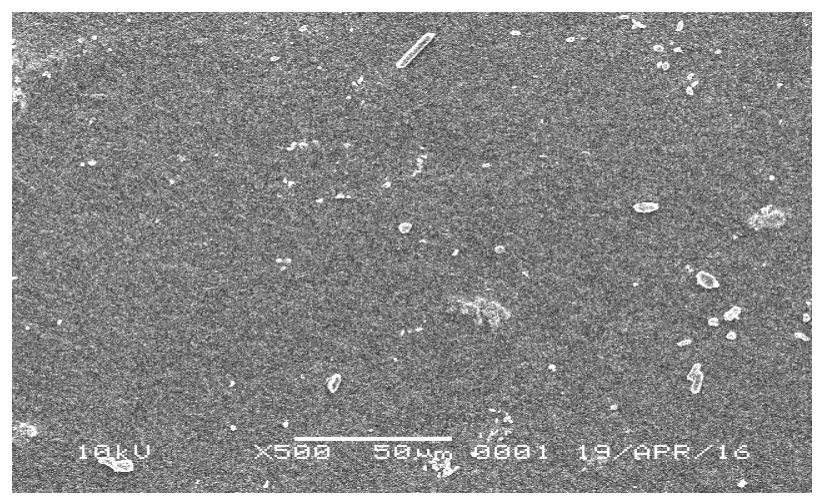

Gambar 3 (a). Analisis SEM membran Kit-PVA-Ligetah $15 \%(\mathrm{w} / \mathrm{w})$ 


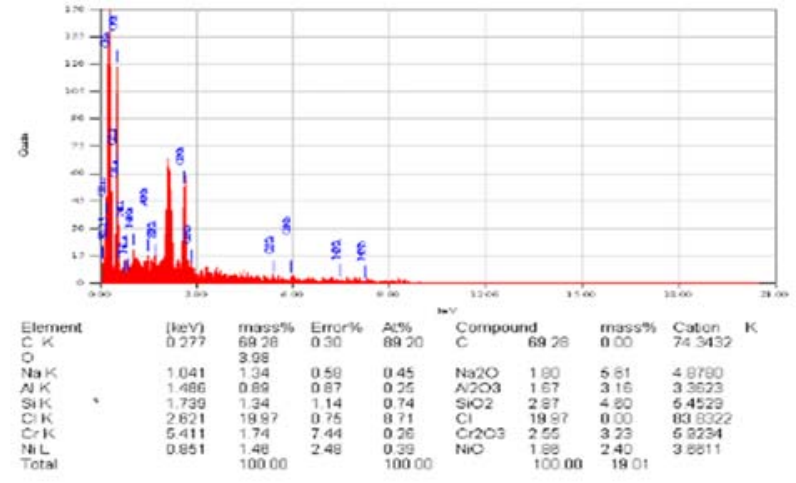

Gambar 3 (b). Analisis EDAX membran Kit-PVA-Ligetah $15 \%(\mathrm{w} / \mathrm{w})$

Scanning Electron Microscope (SEM) dan EnergyDispersive X-Ray Spectroscopy (EDS) merupakan alat yang memiliki kemampuan memberikan informasi secara langsung tentang topografi (tekstur permukaan sampel), morfologi (bentuk dan ukuran), komposisi (ukuran penyusunan sampel) (Qulub, 2011). SEMEDS digunakan karena hasil dari analisis FTIR tidak mendapatkan hasil yang kurang akurat dan tidak menunjukkan perbedaan pik dari semua sampel yang diuji hasil yang didapatkan dari pengujian sampel pada alat SEM-EDS adalah terlihat unsur pada sampel Kitosan-PVA-Li-Getah 5\% (w/w) yaitu karbon $(\mathrm{C})$, oksigen $(\mathrm{O})$, aluminium $(\mathrm{Al})$ dengan senyawa $\left(\mathrm{Al}_{2} \mathrm{O}_{3}\right)$, klor $(\mathrm{Cl})$. Sedangkan sampel Kitosan-PVA-Li-Getah 15\% (w/w) menampilkan unsur karbon $(\mathrm{C})$, oksigen $(\mathrm{O})$, natrium $(\mathrm{Na})$ dengan senyawa $\mathrm{Na}_{2} \mathrm{O}$, aluminium ( $\mathrm{Al}$ ) dengan senyawa $\mathrm{Al}_{2} \mathrm{O}_{3}$, silikon $(\mathrm{Si})$ dengan senyawa $\mathrm{SiO}_{2}$, klorin $(\mathrm{Cl})$, kromium $(\mathrm{Cr})$ dengan senyawa $\mathrm{Cr}_{2} \mathrm{O}_{3}$ dan nikel $(\mathrm{Ni})$ dengan senyawa $\mathrm{NiO}$.

\section{Analisis konduktivitas}

Analisis spektroskopi impedansi dari membran dihasilkan pengolahan konduktivitas pada Tabel 1 dan data pada Gambar 4.

Tabel 1. Data konduktivitas membran elektrolit KitPVA-Li-Getah

\begin{tabular}{llll}
\hline$N_{0}$ & $\begin{array}{c}\text { Berat Penambahan } \\
\text { Getah Terhadap } \\
\text { Membran Elektrolit(\%) }\end{array}$ & R(ohm) & Konduktivitas (S/cm) \\
\hline 1 & Getah 0 & 335070 & $3,43955 \times 10^{-4}$ \\
2 Getah5 & 388130 & $9,11505 \times 10^{-4}$ \\
3 Getah 10 & 507420 & $6,07777 \times 10^{-4}$ \\
4 & Getah 15 & 328630 & $10,99353 \times 10^{4}$ \\
5 & Getah 20 & 1199500 & $3,183676 \times 10^{-4}$ \\
\hline
\end{tabular}

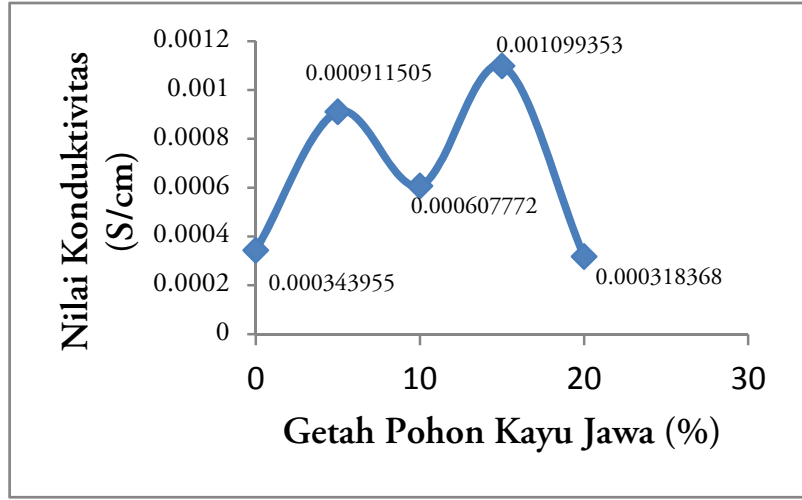

Gambar 4. Grafik hubungan persen berat penambahan getah terhadap nilai konduktivitas membran elektrolit Kit-PVA-Li-getah

Spektroskopi Impedansi Listrik merupakan suatu teknik analisis yang digunakan untuk menentukan impedansi suatu sistem. Impedansi adalah resistansi kompleks dari suatu rangkaian listrik yang merupakan respon terhadap tegangan listrik yang diberikan pada suatu rangkaian. Respon tersebut berupa sinyal arus AC dan dapat diperoleh nilai resistansi dari sistem. Berdasarkan nilai resistansi tersebut kita dapat mencari nilai konduktivitas suatu bahan yang merupakan karakteristik suatu bahan. Data EIS umumnya dianalisis melalui pencocokan data dengan rangkaian listrik sebanding (ekuivalen) dengan menggunakan program Zview2 (Salman, 2014).

Pengukuran konduktivitas ionik terhadap membran polimer elektrolit dilakukan dengan alat Spektroskopi Impedansi untuk mengetahui nilai tahanan dari membran elektrolit yang dihasilkan dan kontribusi gugus ionik pada polimer elektrolit tersebut. Selanjutnya dihitung konduktivitasnya. Nilai konduktivitas ionik dari membran polimer elektrolit dengan penambahan getah 5\%,10\%, 15\%, $20 \%(\mathrm{w} / \mathrm{w})$ dan tanpa penambahan getah $(\mathrm{w} / \mathrm{w})$ ditunjukkan pada Tabel 1.

Data pada Tabel 1 menunjukkan penambahan getah sebagai filler dalam membran elektrolit kitosanpolivinil alkohol-litium memiliki konduktivitas yang beragam. Kurva hasil perhitungan menunjukkan bahwa pada penambahan getah 5, $15(\mathrm{w} / \mathrm{w})$ mengalami kenaikan konduktivitas secara berturutturut yaitu $9,11505 \times 10^{-4}, 10,99353 \times 10^{-4}$. Akan tetapi pada penambahan getah $10 \%$ dan $20 \%(\mathrm{w} / \mathrm{w})$ mengalami penurunan nilai konduktivitas yaitu $6,07777 \times 10^{-4}$ dan 3,183676 $\times 10^{-4}$. Penambahan getah sebagai filler anorganik dapat meningkatkan dan menurunkan konduktivitas dari membran elektrolit itu sendiri.

Peningkatan nilai konduktivitas pada penelitian ini dikarenakan makin tingginya jumlah ion dan mobilitas dari ion-ion yang ada dalam membran elektrolit polimer tersebut. Peningkatan konduktivitas dengan adanya $-\mathrm{SiO}_{2}$ dan alumina yang terdapat pada getah disebabkan karena $-\mathrm{SiO}_{2}$ dan alumina dapat menjadi mobilitas ion $\mathrm{Li}+$ dalam mobilitasnya melalui ikatan Si-O-Li dalam matriks polimer. Selain itu, 
adanya gugus - $\mathrm{OH}$ dari polivinil alkohol dan gugus $\mathrm{NH} 2$ dari kitosan dapat menyebabkan membran polimer elektrolit memiliki hantaran yang baik. Sedangkan penurunan nilai konduktivitas pada penambahan $10 \%$ dan $20 \%(\mathrm{w} / \mathrm{w})$ getah disebabkan karena adanya penambahan Filler yang terus-menerus sampai dengan konsentrasi tertentu akan menurunkan difusi elektron di dalam polimer. Penurunan difusi elektron akan mempengaruhi interaksi kolom antara materi pembawa (silika) dengan sisi-sisi membran (Ghufira, dkk., 2013).

Peningkatan konduktivitas yang disertai adanya ion litium disebabkan litium merupakan unsur logam paling ringan dan memiliki potensial redoks sangat rendah $\left(\mathrm{E}\left(\mathrm{Li}^{+} / \mathrm{Li}\right)=-3,04 \mathrm{~V}\right)$, yang memungkinkan sel memiliki tegangan tinggi dan densitas energi besar. Selain itu, ion $\mathrm{Li}^{+}$memiliki jari-jari ion kecil yang menguntungkan untuk difusi dalam padatan dan dalam hal ini merupakan membran elektrolit polimer (Marareza, 2014)

Penurunan konduktivitas dapat terjadi karena kelompok-kelompok gugus hidrofilik (gugus-gugus asam) yang terpisah dalam skala nano dari bagian hidrofobik membrane membentuk terowongan (channel) yang berkelok-kelok dan tersekat (aliran elektron tertutup), tidak memungkinkan terjadinya aliran elektron, akibatnya konduktivitas membran menurun. Kelompok-kelompok hidrofilik yang membentuk terowongan (channel) yang lurus, menghasilkan konduktivitas proton yang tinggi seperti yang diilustrasikan pada Gambar 5 (Gonggo, 2011).

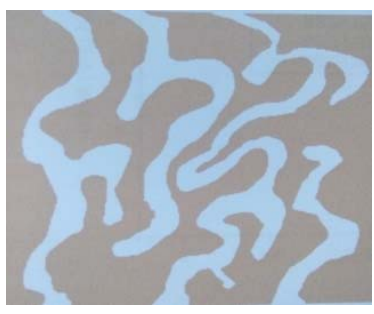

(a)

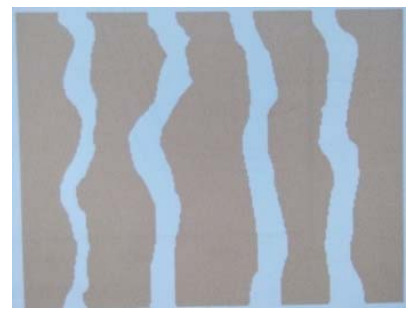

(b)
Gambar 5. Ilustrasi kelompok-kelompok gugus hidrofilik dalam membrane elektrolit (a) berkelokkelok dan buntu, dan (b) lurus-lurus (Gonggo, 2011).

Berdasarkan data konduktivitas yang diperoleh di atas, untuk membran elektrolit penambahan getah dengan variasi $5 \%, 10 \%, 15 \%$ dan $20 \%(\mathrm{w} / \mathrm{w})$ dan tanpa penamahan getah telah memenuhi standar untuk dijadikan suatu baterai. Hal ini mengacu pada pendapat Linden (2002) bahwa standar konduktivitas suatu membran polimer yang diaplikasikan dalam suatu baterai adalah $10^{-7} \mathrm{~S} / \mathrm{cm}-10^{-3} \mathrm{~S} / \mathrm{cm}$.

\section{Analisis uji perbandingan voltase antara baterai berbahan dasar elektrolit polimer dengan baterai komersial \\ Hasil pengujian voltase antara baterai berbahan dasar elektrolit polimer dengan baterai komersial dapat dilihat pada Tabel 2 dan data dalam bentuk grafik disajikan pada Gambar 6 .}

Tabel 2. Data voltase baterai membran elektrolit

\begin{tabular}{ccc}
\hline No & $\begin{array}{c}\text { Berat tanpa getah dan } \\
\text { penambahan getah terhadap } \\
\text { membran elektrolit (\%) }\end{array}$ & $\begin{array}{c}\text { Voltase } \\
\text { (Volt) }\end{array}$ \\
\hline 1 & 0 & 1,5 \\
2 & 5 & 1,5 \\
3 & 10 & 1,5 \\
4 & 15 & 1,5 \\
5 & 20 & 1,4 \\
\hline
\end{tabular}

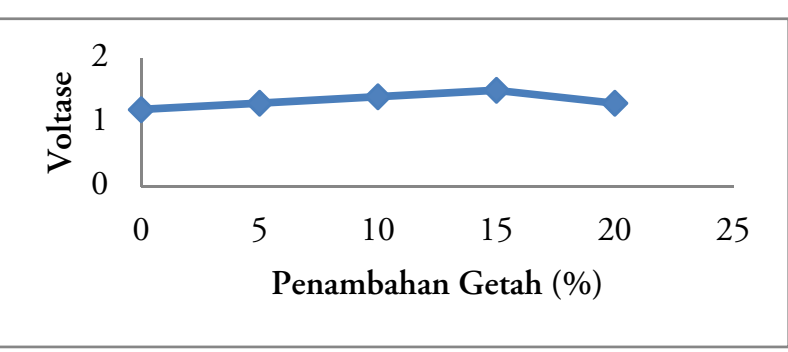

Gambar 6. Grafik hubungan persen berat penambahan getah terhadap nilai voltase baterai elektrolit Kit-PVA-Li-Getah

Pengujian voltase dilakukan pada rangkaian terbuka, dimana pada baterai berbahan dasar polimer elektrolit penambahan getah $20 \%$ memiliki nilai voltase yang sangat kecil yaitu 1,4 Volt sedangkan pada penambahan getah $5 \%, 10 \%$ dan $15 \%$ dan tanpa penambahan getah memiliki nilai voltase yang sama yaitu 1,5 Volt.

Pada penelitian ini, voltase tertinggi yakni pada persen berat penambahan getah $0 \%, 5 \% .10 \%$ dan $15 \%$ senilai 1,5 Volt. Tetapnya nilai disebabkan karena pembuatan baterai masih dilakukan secara manual sehingga kerapatan elektrolit polimer baterai masih belum baik (Lateene, 2014). Linden (2002) menyampaikan bahwa desain dari baterai dapat mempengaruhi nilai dari tegangan serta arus baterai. Tetapi baterai dengan polimer elektrolit memiliki kelebihan, yaitu bersifat ramah lingkungan dan fleksibel.

Nilai tegangan yang dimiliki baterai berbahan dasar polimer dengan penambahan getah sama dengan nilai tegangan yang dimiliki baterai komersial pada umumnya yaitu sebesar 1,5 Volt. Berdasarkan karakteristik ini baterai berbahan dasar elektrolit polimer dapat diaplikasikan sebagai baterai (Riyanto, dkk., 2011).

Baterai berbahan dasar polimer elektrolit yang ditambahkan dengan garam litium memiliki mekanisme kerja, dimana ketika anoda dan katoda terhubung maka elektron akan mengalir dari anoda menuju katoda melalui sirkuit luar. Pada kondisi ini listrik pun akan mulai mengalir. Dibagian dalam baterai terjadi sebuah proses pelepasan ion litium pada anoda, kemudian ion tersebut akan berpindah menuju katoda melalui elektrolit (Mihai, 2012).

\section{Kesimpulan}

Berasarkan analisis hasil penelitian menunjukkan bahwa membrane Blend Kitosan-PVA-Li-Getah 
pohon kayu jawa telah dikarakterisasi. Spectrum FTIR menunjukkan bahwa senyawa Kitosan-PVA-LiGetah pohon kayu jawa merupakan kombinasi senyawa blend kitosan, PVA, Litium dan Getah pohon kayu jawa yang mengandung silica $\left(\mathrm{SiO}_{2}\right)$. Hasil analisis spektoroskopi impedansi juga menunjukkan bahwa penambahan getah pohon kayu jawa kedalam blend kitsan-PVA secara umum meningkat. Demikian juga hasil pengukuran voltase meningkat dengan meningkatnya penambahan konsentrasi getah pohon kayu jawa.

\section{Ucapan Terima Kasih}

Ucapan terima kasih penulis berikan kepada laboran Laboratorium Kimia FKIP Universitas Tadulako, laboran Laboratorium Kimia Fisik FMIPA Institut Teknologi Bandung, laboran Pusat Penelitian Geologi Kelautan yang telah banyak membantu penulis dalam menyelesaikan penelitian ini.

\section{Referensi}

Dinesh, V. (2008). Lannea coromandelica indian ash tree. Retrieved 10 februari, 2016, from http://lannea-coromandelica-indian-ashtree.html

Erizal, Perkasa, D. P., Aziz, S. \& Sulistioso, G. S. (2013). Modifikasi fisiko kimia membran komposit kitosan polivinil alkohol hasil casting dengan teknik induksi iradiasi gamma. Jurnal Sains Materi Indonesia, 14(3), 166-172.

Fessenden, R. J. \& Fessenden, J. S. (1986). Kimia organik Jilid 2. Jakarta: Erlangga.

Ghufira, Yudha, S. P., Angasa, E., Triyogo, F. \& Fitrianingsih, E. (2013). Studi konduktivitas ionik polimer elektrolit peo-bentonit-liclo4 dan peo-getah damar-liclo4. Prosiding Semirata FMIPA Universitas Lampung, 2013, 143.

Gonggo, S. T. (2011). Sintesis dan karakterisasi membran polimer elektrolit dari bahan polistiren untuk aplikasi sel bahan bakar (fuel cell). (Disertasi). Bandung: Institut Teknologi Bandung

Hassan, C. M. \& Peppas, N. A. (2000). Structure and aplication of poli(vinyl alcohol) hydrogel produced by conventional crosslinking or by freezing/thawing methods. Advertise Polymer Science, 153(8), 37-38.

Imam, M. Z. \& Moniruzzaman, M. (2014). Antinociceptive effect of ethanol extract of leaves of lannea coromandelica. Journal of Ethnopharmacol, 1(154), 10-15.

Joni, M. (2007). Diktat kuliah pengantar biospektroskopi. Bandung: Universitas Padjajaran.

Lateene, R. (2014). Pengaruh kaolin terhadap membran blend kitosan-polivinil alkohol-litium sebagai membran elektrolit untuk aplikasi baterei ion litium. Skripsi. Palu: Universitas Tadulako.
Linden, D. (2002). Primary batteries- introduction handbook of batteries 3ed. USA: The McGrawHill Companies.

Marareza, H. (2014). Pengaruh bentonit terhadap membran blend kitosan-polivinil alkohol-litium sebagai membran elektrolit untuk aplikasi baterai ion litium. Skripsi. Palu: Universitas Tadulako.

Mihai, C. (2012). Baterai lithium. Retrieved 20 juni, 2016, from http://elkimkor.com/2012/07/27/baterailithium.

Minami, T., Tatsumisago, M., Wakihara, M., Iwakura, C., Kohjiya, S. \& Tanaka, I. (2005). Solid state ionics for batteries. Gakuencho Sakai Osaka Japan: Osaka Prefecture University.

Mohamed, N. S., Subban, R. H. Y. \& Arof, A. K. (1995). Polymer battries fabricated from lhitium complexed acetilated chitosan. Journal of Power Sources, 56(2), 153-156.

Paradossi, G., Lisi, R., Pacci, M. \& Crescenzi, V. (1996). New hydrogels based on poly(vinylalcohol). Journal of Polymer Science: Part A, polymer, chemistry, 34, 3417-3495.

Qulub, M. (2011). Scanning electron microscope energy. Retrieved 19 juli, 2016, dari http://munawirulqulub.blogspot.co.id

Rahmawati, S. \& Gonggo, S. T. (2013). Sintesis membran elektrolit kitosan untuk aplikasi ion litium. Prosiding seminar nasional sains dan matematika II (C-07), 302-305.

Razak, T., Winie, F. S. A., Ghani \& Ahmad. (2008). Conductivity and ftir studies on pva /chitosanlicf2so3. Solid State Science and Technology, 16(1), 1-7.

Riyanto, B., Maddu, A. \& Dewi, R. S. (2011). Baterei cerdas dari elektrolit polimer kitosan-pva dengan penambahan amonium nitrat. Jurnal Pengolahan Hasil Perikanan Indonesia, 16(2), 70-77.

Robinson, W. R. (1997). General chemistry. Tenth edition. New York: Houghton Mifflin company, Boston

Saehana, S., Muslimin \& Abdullah, M. (2014). Electrochemical impedance spectroscopy study of $\mathrm{TiO}_{2}$ based solar cells. Journal of Renewable and Sustainable Energy, 6(2014), 1-6.

Sastrohamidjojo, H. (2007). Spektroskopi. Yogyakarta: Liberty.

Subban, R. H. Y., Arof, K. \& Radhakrishna, S. (1996). Polymer batteries with chitosan electrolyte mixxed with sodium perchlorate. Material Science and Engineering, B38, 156-160.

Syahril. (2012). Studi spektroskopi impedansi barium titanat pada temperatur tinggi. Skripsi. Jakarta: Universitas Indonesia. 